\title{
Weak street-level enforcement of tax laws: the role of tax collectors' persistent but broken public service expectations
}

\author{
Moritz Schmolla
}

${ }^{a}$ Department of International Development, London School of Economics and Political Science, London, United Kingdom

Department of International Development

LSE

Houghton Street

London WC2A 2AE

m.schmoll@1se.ac.uk

\begin{abstract}
What drives ineffective tax collection in developing countries? This widespread phenomenon has been explained by weak 'state capacity', rent-seeking bureaucrats, or the influence of political elites. More recently, scholars have also emphasised the role of 'moral economies', shared notions of what constitutes fair and legitimate taxation that prevent tax collectors from strictly enforcing the law. However, the literature has thus far missed the ways in which shared notions of what constitutes fair work and employment in the tax administration affect collection. Drawing on two years of fieldwork in Egypt, including ethnographic research among street-level tax collectors, the article finds that the simultaneous persistence and disappointment of historical expectations and feelings of entitlement to a white-collar, middle-class job renders tax collectors unwilling to carry out vital enforcement tasks, and further impedes the building of administrative capacity. Furthermore, the administrative leadership's buying-into such narratives hollows out its capability to incentivise tax collectors to change their ways. These findings have important implications for our understanding of the micro-foundations of governance and state capacity, underscoring the role of normative-ideational factors not only in shaping the willingness of taxpayers to pay taxes, but also of tax collectors to collect them.
\end{abstract}




\section{Introduction}

What drives weak enforcement of tax laws? This widespread phenomenon in the developing world has been explained by, amongst other things, weak state capacity, rentseeking bureaucrats, neopatrimonialism, or the power of economic and political elites (Bird, 1989; Radian, 1980; Tanzi and Zee, 2000; von Soest, 2007). More recently, the literature has also begun paying greater attention to how tax collectors can deliberately choose to refrain from applying the law (Cirolia and Mizes, 2019; Piracha and Moore, 2016; Prichard and van den Boogaard, 2017; Twijnstra et al., 2014). Authors of this new wave of scholarship have highlighted how leniency is often a consequence of prevalent moral economies, of shared notions between taxpayers and tax collectors of what constitutes fair and legitimate tax collection.

However, in this article I argue that such 'state-society' moral economies are only one part of the theoretical picture. Scholars have thus far missed how intra-state moral economies affect the effectiveness of tax collection. In other words, how do tax collectors' normative views and expectations of what the state should do and provide concretely affect their behaviour on the job? And what are the effects of the acknowledgment of such a moral responsibility by the state and its administrative leadership?

Focusing on the case of Egypt, a country with much weaker tax collection than its broader structural characteristics would predict, I argue that tax collectors' broken expectations in terms of what their job ought to entail, what their position in society ought to be, and what the state ought to provide for its employees, shape their job performance. Drawing on data from historical research and two years of in-depth fieldwork in Egypt, in particular ethnographic research among tax collectors, the paper retraces these normative expectations to a public service bargain which took shape over the course of 
the $19^{\text {th }}$ and $20^{\text {th }}$ centuries. Concretely, persistent expectations with respect to the quality of work, the wider social status of civil servants, as well as the specific status of tax collectors on the one hand, and the state's breaking of these caretaker promises on the other, render tax collectors unwilling to do their jobs. Furthermore, the article demonstrates how potential remedies such as performance-based management relying on rewards and sanctions are rendered ineffective by this very same public service bargain.

The article has implications for our understanding of tax collection, as well as the micro-foundations of state capacity, effective governance and service delivery. Committed, dutiful, and motivated civil servants are crucial to these ends. Scholars, experts, and practitioners are well aware of the fact that in many developing countries these can be in short supply but still often limit their analysis to diagnosing 'weak capacity', 'low morale', or 'resistance to change' without seeking to fully grasp their historical, political and sociological origins and underpinnings. Paying closer attention to how public service expectations shape the behaviour of frontline workers is therefore essential for a more fine-grained understanding of effective everyday governance.

The paper is organised as follows. Section 2 revisits existing scholarship while Section 3 lays out the research methodology. Section 4 retraces Egypt's public service bargain. Section 5 shows how high expectations clash with the practical realities of vital but undesirable collection tasks. Section 6 then link views of a state not holding up its end of the social contract to other common 'bureaucratic pathologies' such as absenteeism, idleness, or corruption. Section 7 discusses how a moral economy of bonuses undermines potential remedies such as performance-based management. Section 8 concludes.

\section{Explaining everyday tax enforcement}


How has the literature explained the ineffective collection of taxes? First, it has been attributed to weak state capacity. Accordingly, the limited resources and reach of the public administration result in weak enforcement (Bird, 1989; Fukuyama, 2004; Mann, 1984; Tanzi and Zee, 2000). Others have argued that ineffective tax collection followed from the neopatrimonial nature of some states (von Soest, 2007; von Soest et al., 2011). As the theory goes, the ruler intervenes in the functioning of the tax administration for political and private gain. Yet others have argued that whether taxes are effectively collected depends to a large extent on the power of economic and political elites (Best, 1976; Fairfield, 2015; Prichard, 2009). Because of these groups' bargaining power and disproportionate influence, they are able to resist taxation. Sometimes, politicians may also thwart the enforcement of laws for the benefit of society's poor (Holland, 2016; Tendler, 2002).

Despite their valuable contributions these theories share two limitations. First, they tend to overlook the ways in which normative-ideational factors can shape tax collection, in particular the potential effects of historical social contracts on the state apparatus. Second, they largely adopt a top-down perspective in which 'the ruler' decides whether or not to apply the law, seemingly ignoring research in public administration on the agency of 'street-level bureaucrats' (Lipsky, 1980; Maynard-Moody and Musheno, 2012).

Rational choice theory does take on a micro-level perspective and holds that tax collectors often do not pursue strict enforcement because it is not rational for them to do so based on incentives they face within their organisation (Moore, 2014; O'Brien and Li, 1999; Radian, 1980), or because of the principal-agent problem (Mukherjee, 2001; Winter, 2000). It certainly offers one of the most compelling theories for understanding the behaviour of bureaucrats. But while principal-agent theory tells us that the inability 
of managers to adequately monitor the actions of interface-level workers is to blame for weak enforcement, it is often doubtful whether they actually lack information about their subordinates. And as has already been established for taxpayers and actors more generally, tax collectors' perception of and response to incentives will to a certain extent always be dependent on their normative universe and explains why people do not always behave rationally (Berman, 2001; Sen, 1977; Wenzel, 2005). That this normative universe of the tax collector has received little attention is puzzling given that scholars are largely in agreement over the influence of taxpayers' expectations, norms, and attitudes for explaining their (un)willingness to pay taxes (D'Arcy, 2011; Goodfellow and Owen, 2018; Levi, 1988; Posner, 2000; Wenzel, 2005).

Recently though, interest in the normative-ideational dimension of taxation has begun to increase (Cirolia and Mizes, 2019; Piracha and Moore, 2016; Prichard and van den Boogaard, 2017). But thus far research has been largely focused on how normative views shared by tax collectors and taxpayers can weaken enforcement. The mutual expectations and implicit and explicit agreements between tax collectors and the state are largely unchartered territory. What do the former actually think about and expect from their job, their bosses, the state, their interactions with the public? What do they feel like doing, what don't they? Even a look at area-specific social science scholarship on taxation, for example Samer Soliman's study of Egyptian fiscal politics under former president Mubarak, shows a dearth of scholarship on tax collectors (Soliman, 2011; Waterbury, 1997).

To be sure, the slate we start with is not entirely blank. In a brief passage of a chapter by Anuradha Joshi and Joseph Ayee, the authors point out the lack of interest of Ghanaian tax collectors, in particular more educated ones, to work in the informal sector, because it is viewed as "not being "professional"' and potentially detrimental to their 
careers (Joshi and Ayee, 2008, p. 190). But Joshi and Ayee seem to frame their analysis in terms of career incentives. Bigger questions with respect to how tax collectors relate to the state and how this affects their work still remain underexplored, which is presumably also why Joshi et al. have later called for 'more research on the perspectives of [tax] administrators' (Joshi et al., 2012).

To this end, I believe a turn to public administration and anthropology can be fruitful. The literature on so-called 'public service bargains', or 'any explicit or implicit understanding between (senior) public servants and other actors in a political system over their duties and entitlements relating to responsibility, autonomy and political identity, and expressed in convention or formal law or a mixture of both' puts forward a useful concept (Hood, 2000, p. 8). However, it has in the literature on public administration mostly been used to understand the political economy of administrative reform and the changing roles of senior civil servants, not to study the work performance of street-level bureaucrats. To address this latter aspect, I drew on the 'States at Work' approach rooted in Africanist anthropology, that seeks to uncover 'how public bureaucrats see their world, how they are perceived by the citizens to which they deliver services, and how they deal on a routine basis with their hierarchy, their colleagues, other non-state institutions, and the users of public services' (Bierschenk and Olivier de Sardan, 2014, p. 55). By harnessing the respective strengths of these disciplinary approaches I believe it is possible to address the aforementioned shortcomings of the literature. In the following section, I briefly describe how I practically went about it.

\section{Methodology}

This paper is a product of a longer-term research project on the history and politics of tax collection in Egypt. The country is a particularly poor performer with an unusually low 
tax intake (10.3\% of GDP on average between 2005 and 2015) in comparison to what one would expect based on structural characteristics commonly considered to determine taxto-GDP ratios. ${ }^{1}$ Moreover, since the 1980 s Egypt's tax intake has experienced a sustained and significant decline (Soliman, 2011).

Figure 1. Egyptian tax intake (excluding taxes on external rent), 1976-2015*

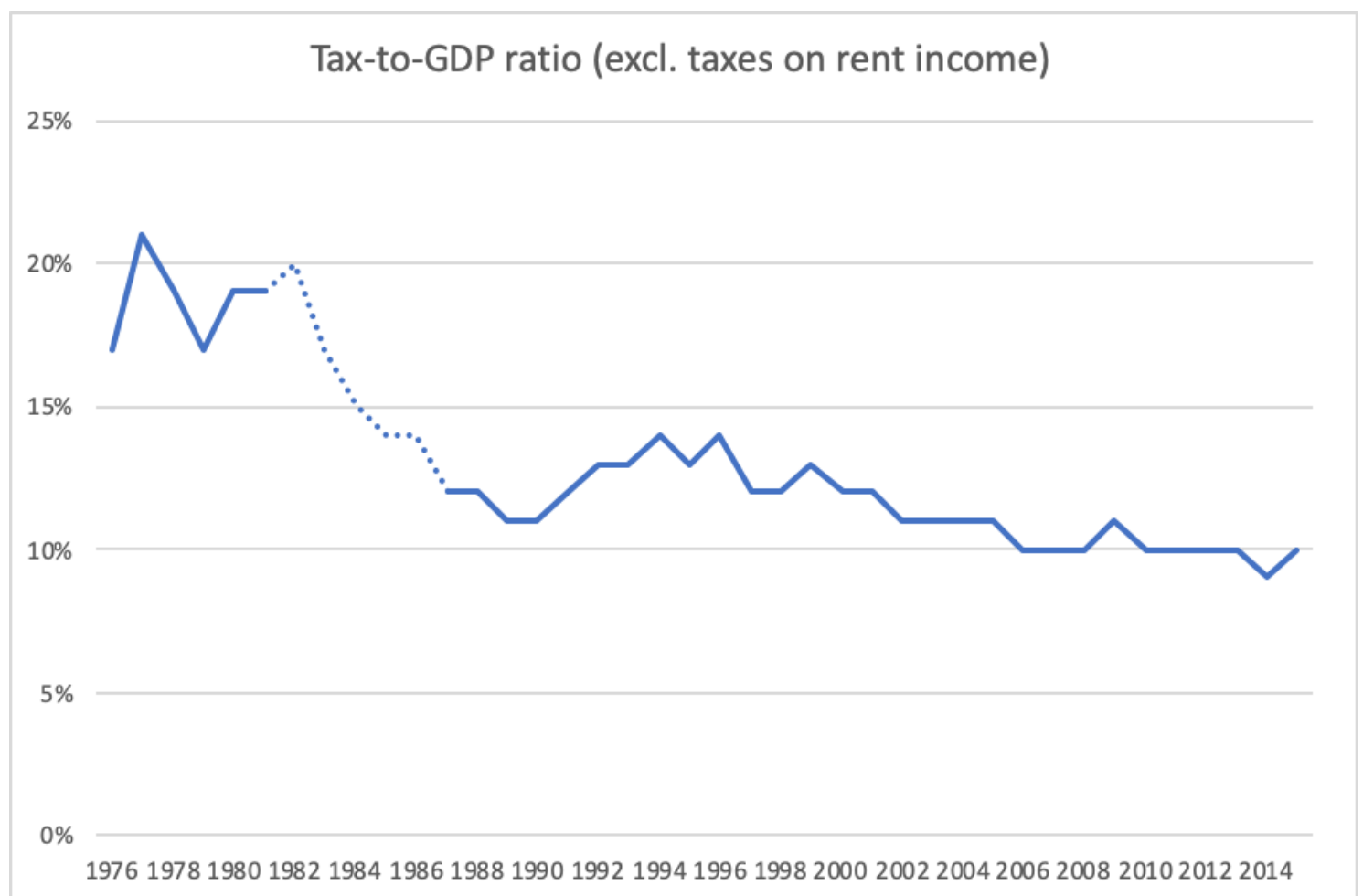

* No reliable data that excluded corporate taxes on the Egyptian General Petroleum Company and the Suez Canal Authority was available for the years 1982-1986. The dotted line plots own estimates based on aggregated tax revenues reduced by one third.

Sources: 1976-1981 (Ahmed, 1984); 1982-1986: UN Statistical Yearbooks; 1987-2015: ICTD dataset (Prichard et al., 2014).

Indeed, while in the early 1980s Egypt's tax effort ${ }^{2}$ was said to 'compare favourably with other countries' (Ahmed, 1984, p. x), decades later studies categorise Egypt as 'low effort' and further found it to belong to a group of only seven countries that 'lowered their tax effort after 2001' (Le et al., 2012, p. 18; Pessino and Fenochietto, 2010).

The case is particularly puzzling when one considers the overall strong administrative development and reach of the Egyptian state in comparison to Sub-Saharan 
African or South Asian countries, which are often the focus of the tax literature. The country's two tax administrations, the Egyptian Tax Authority (ETA) and the Egyptian Real Estate Tax Authority (ERETA) each have, respectively, 223 and 334 local tax offices covering all parts of the national territory, and the number of tax collectors per inhabitant is on par with developed countries such as Germany. ${ }^{3}$

Studying the effect of expectations, norms or attitudes calls for surveys or for ethnographic research. For this research project, I prioritised depth and detail that surveys generally won't reveal. In addition, surveys require a high degree of state co-operation and I would argue that state apparatuses that are accepting of having a foreign researcher conduct surveys amongst their employees are likely to be different in non-random ways.

For the purpose of the larger research project, I conducted two years of in-depth fieldwork, which combined archival research and 'site-intensive methods' (Kapiszewski et al., 2015). I carried out roughly 70 interviews with taxpayers/non-taxpayers, accountants and lawyers, former ministers of finance, consultants and experts, and I further undertook ethnographic fieldwork among ordinary tax collectors in Cairo and Ismailia. In addition to time spent socialising, observing, and conducting informal conversations, I also conducted around 20 long, semi-structured interviews with tax collectors and a few mid-level managers, which will constitute the main source of data for this paper. I complemented the data I gathered with online video and press material published online on everyday tax collection and/or by interface-level tax collectors.

\section{Retracing the Egyptian public service bargain}

A 'public service bargain' (PSB) is an 'explicit or implicit agreement between public servants - the civil or uniformed services of the state - and those they serve' (Hood and Lodge, 2006, p. 6). Every country has a more or less formally defined relationship 
between the state, politicians, and the public on the one hand, and the civil service on the other. It constitutes an 'important informal institution' that emerges and evolves through historical developments and choices at critical junctures, but also long term practices and conventions that govern the recruitment, terms of service (including pay, status, job security, and so forth), rights and duties, and roles and responsibilities of civil servants (Helmke and Levitsky, 2004; Hood and Lodge, 2006, p. 6).

In this section, I retrace the emergence and evolution of the Egyptian PSB, as well as the socio-historical position of Egyptian tax collectors. The point of this analysis is not to suggest that the Egyptian case is fundamentally unique but rather a particularly illustrative case of how certain historical trends have shaped tax administrations in developing countries. ${ }^{4}$ Indeed, throughout the Global South, state-building in a context of late development often meant that public administrations played a much more significant role as an employer, in particular of the educated middle classes, than in countries that industrialised earlier and developed strong domestic private sectors. Furthermore, to different degrees and for varying lengths of time, many post-colonial governments experimented with socio-economic policies similar to the ones implemented in Egypt under Gamal Abdel Nasser (1952-1970). ${ }^{5}$ And perhaps even more so than Egypt, many countries have in the wake of the Structural Adjustment Programmes (SAPs) of the 1970 s and 1980s also witnessed significant transformations of their public administrations.

Over the course of the $20^{\text {th }}$ century, and in particular since Nasser's presidency, a normative consensus around the moral responsibility of the state to provide for its citizens and its employees developed in Egypt, giving way to widespread expectations in terms of social citizenship rights and professional entitlements. As one of the main groups of 
beneficiaries of Nasserist policies, civil servants came to view it as a duty of the state to ensure a certain type of job quality and lifestyle.

In fact, the Egyptian PSB's roots reach back to state-building efforts in the $19^{\text {th }}$ century, when schools were almost solely built to provide recruits for the expanding state apparatus, and conversely almost all graduates expected to work for the government (Farag, 2001). In the post-colonial era this relationship was entrenched. Nasser oversaw a massive expansion of the state apparatus which became the "core of a distributive social coalition that nurtured urban and rural middle classes' (Adly, 2015). In the 1960s, when Nasser's policies took a decidedly socialist turn, the government began formalising what had at that point already been a decade-old implicit social contract, and a government job was indeed guaranteed to every university and vocational secondary school graduate (Assaad, 1997, pp. 86-87).

To be sure, historically government jobs were, for the most part, never very well paid. But many civil servants could aspire to a modest middle-class life because under Nasser subsidies and restrictions on the flow of capital and goods ensured that consumption patterns in society did not diverge as strongly. Job security was extremely high, and further strengthened even in the midst of Anwar el-Sadat's partial economic liberalisation. On top of that came perks that were available to a number of civil servants - such as the use of dedicated social clubs, medicinal facilities, holiday resorts, and so forth. In the public imagination a civil service job therefore became a promise of a modest but decent and stable lifestyle.

That such policies have a lasting impact on people's expectations, all the while the vast majority of today's Egyptian tax collectors have not personally worked and some not even lived during the Nasserist era, is on the one hand supported by previous scholarship (Alesina and Fuchs-Schündeln, 2007), and on the other evidenced by field 
data presented in this paper as well as survey data from the World Values Survey. Indeed, Egyptians still display a strong attachment to the notion of a 'caretaker state' with an active role in the economy and ensuring that all its citizens are provided for:

Table 1. Normative expectations of a caretaker state

\begin{tabular}{|l|c|c|c|}
\hline & Egypt & $\begin{array}{c}\text { Lower-income } \\
\text { countries (LICs) }\end{array}$ & $\begin{array}{c}\text { Middle-income } \\
\text { countries (MICs) }\end{array}$ \\
\hline $\begin{array}{l}\text { The government should } \\
\text { take more responsibility } \\
\text { to ensure that everyone } \\
\text { is provided for (1 - less } \\
\text { responsibility to 10- } \\
\text { more responsibility) }\end{array}$ & $7.3^{*}$ & & \\
\hline $\begin{array}{l}\text { Government ownership } \\
\text { of business should be } \\
\text { increased (1 - more } \\
\text { private ownership to 10 } \\
\text { - more state ownership) }\end{array}$ & $6.8^{* *}$ & 6.2 & 6.1 \\
\hline
\end{tabular}

*Egypt deviates by 1.18 and 1.07 standard deviations (SD) from LICs and MICs respectively.

**Egypt deviates by 2.8 and 1.8 SD from LICs and MICs respectively.

Source: World Values Survey, $6^{\text {th }}$ wave, 2014.

While the figures in the table above reflect the views held by the population as a whole, civil servants are without a doubt among the groups in society that push the country's average up, indicating even more strongly-held views by Egypt's bureaucrats.

A job in the tax administration was historically, and still is, linked to higher prestige and pay compared to many other civil service jobs. ${ }^{6}$ However, it is important to specify here that there are actually two different tax administrations in Egypt. The ETA, responsible for income, profit, capital, and consumption taxes was the result of a 2006 merger of the General Tax Authority (founded in 1939) and the Sales Tax Authority (founded in 1991). The second tax administration is the ERETA and was founded in 1883. ${ }^{7}$ It is responsible for collecting taxes on built properties, agricultural land, and entertainment venues. Work for the ETA requires greater knowledge of tax law and accounting, whereas ERETA employees, once the value of property has been calculated 
for a period of several years, are basically simple collectors. ERETA offices outside Cairo were since 1974 affiliated with the chronically underfunded municipalities and not with the Ministry of Finance $(\mathrm{MoF})$. Career progression was limited and pay was extremely poor, lagging far behind ETA employees, although they eventually managed to achieve wage parity - amounting to a $325 \%$ increase - through a powerful social movement in 2007-2008 (Beinin, 2009; Bishara, 2015; Lachapelle, 2012).

Since Sadat's (1970-1981) and Mubarak's (1981-2011) rule, the Egyptian PSB has come under significant strain without however being officially and altogether abandoned. Under increasing severe fiscal constraints, the state progressively reneged on the terms of the bargain, as 'queuing' for public sector jobs, real wage erosion, and low levels of investment spread continuously (Assaad, 1997). And yet, in public discourse as in law, successive governments were intent on keeping changes to the civil service to a minimum, and certainly managed to do so in comparison with countries in Sub-Saharan Africa for example, where SAPs led to a complete redefinition of the role and scope of the state apparatus (Bierschenk, 2014).

In the following sections, I show how the simultaneous persistence and breaking of these expectations contributes in various ways to the weak enforcement of tax laws.

\section{How disappointed expectations hinder vital enforcement tasks}

Despite increasing automation of tax collection, most taxes still have a role for human administration and, in particular, for fieldwork (including in developed countries). Both the ERETA and the ETA send staff to visit offices, factories, shops, farms, and built properties. Their job consists, among many other things, of registering and assessing properties, auditing businesses, serving debt and arrear notices, and so forth. These tasks 
are vital for an effective enforcement of tax laws and signal to taxpayers that they cannot evade their liabilities without consequence.

One theme emerging from the fieldwork data was that of a strong disconnect between tax collectors who saw themselves as deserving of a decent, white-collar office job, but were in fact asked to deal with people and areas they considered inappropriate in terms of levels of poverty, education, cleanliness, and safety. Contrary to what has previously been written on this subject, these views are not only relevant when it comes to taxing the informal sector but depending on the administration or the staff may more generally characterise attitudes towards formal but less affluent areas (Joshi and Ayee, 2008, p. 190).

Field work that would have to be carried out in certain areas of the country deemed beneath a tax collector was indeed viewed particularly negatively and some street-level tax collectors shared negative perceptions and stories of certain areas or neighbourhoods. They considered them populated with uneducated, unfriendly, or even overtly hostile people. A worker for the central Cairo corporation tax office - a fairly prestigious department to be working in - stated, for example:

There are places I can't go, you know some places like... [...] Let me give you an example, this happened even before the revolution. A friend of mine went to Gamaleyya, a normal street with shops and there he went to a butcher. He came in and introduced himself, 'I'm so-and-so from the tax authority, I'm here to get some information', and they said ok, welcome, but then they shut the door and started beating him. Do you think that I want to go to a place like this again? ${ }^{8}$

Gamaleyya, ${ }^{9}$ a district in Cairo's old town where the famous tourist bazaar Khan El Khalili is located, is not an 'informal neighbourhood'. It is within the legal borders of Cairo and while its buildings are old they were not the result of illegal encroachment on land. It is, however, like many of Cairo's oldest districts perceived as a modest, lowerclass neighbourhood. One which some civil servants with a higher self-perception of their 
status may not wish to venture to. Other tax collectors I spoke to had similar stories to tell:

You go to a rural area in the country, to farmers, to some uneducated people, you explain to them [why you came] [...]. Do you think people will be friendly with you? They will attack you! I'm serious. ${ }^{10}$

Not everybody is nice and respectful, they might harass or verbally abuse you or shut the door behind you. ${ }^{11}$

Now, one could argue that this aversion to do certain jobs in particular areas is a product of the security context immediately after the 2011 uprising and the 2013 coup d'état, marked by increased levels of crime but also insurgencies in Northern Sinai and Upper Egypt. Some tax collectors indeed mentioned that initially work was 'difficult', that 'things aren't working well'. ${ }^{12}$ However, I found attitudes like the ones quoted above to have extended well into el-Sisi's presidency, when public order was once again much more strictly enforced.

From statements like the above it becomes clear how university graduates who entered a fairly well-regarded public administration can very quickly be put off by many vital tasks in the areas of taxpayer registration, collection, audit, and anti-evasion. This means that such tasks are often poorly executed. Tax collectors reported that people would often just go to certain places pro forma or sometimes 'not bothering' at all. ${ }^{13} \mathrm{In}$ addition, it makes it harder for managers to allocate resources to vital tasks. Most tax workers I talked to suggested that perhaps somewhere around $1-2 \%$ of staff of local tax offices was allocated to tasks such as taxpayer registration, and that it was extremely difficult for ETA officials to move staff to where it was most needed.${ }^{14}$ Field employees of both the ETA and ERETA suggested that in particular for ETA employees, who historically have been better paid and educated, it was difficult to reconciliate their 'maktabi' (office-based) job culture expectations with the realities of on the ground tax work in Egypt, arguing that they were people 'who belong to the office'. ${ }^{15}$ 
Surprisingly, some managers seems to be understanding of many people's expectations being more those of a fairly laid-back office job with decent working conditions and hours (a point to which I shall return in subsequent sections). A meeting I witnessed while sitting in an office of an ETA building in eastern Cairo illustrates this. A woman who had recently begun working in the ETA joined us and enquired about a possible transfer. She was working in a local tax office in southern Cairo but was tired of the stressful and demanding working environment. While due to her limited experience the manager did not agree to her proposition that she joins the elite LTC, he suggested a transfer to the department working on liberal professions. The work environment would be nice, with 'clean' offices, and one would deal with 'respectable and educated people' who knew what they were talking about. The manager also emphasised that work would be easy and that she would be able to leave every day by 2 p.m..

PSB-rooted job expectations not only affect the effective deployment and allocation of administrative 'capacity', but also its building. An illustration is the 2015 attempt by the ETA to move workers - mainly those specialising in liberal professions from the lower-middle-class neighbourhood of Haram/Faisal, on the way to the Pyramids in Giza in the south west of Greater Cairo, to Omraniyya/Monib, a more lower-class area closer to the metropolis' Ring Road. On television programmes covering the conflict between workers and the leadership, employees argued that 'the location is not safe, there is no transport except for the Tuk Tuk [motorised rickshaw], and garbage is spread around the new building'. ${ }^{16}$ While they also complained that geographically it would distance themselves from where most of their taxpayers were concentrated, the central point of contention was very clearly the move to an area deemed unworthy of Egyptian civil servants. Eventually, the leadership cancelled the move. 
This underscores how much the building of state capacity is in fact dependent on the PSB and how civil servants perceive their status relative to others in society. This is not an exclusively Egyptian phenomenon. In numerous developing countries the civil service, and more specifically its skilled parts, has historically been the purview of educated urban middle classes who looked to the state for decent, steady, and not overly demanding white-collar jobs - a working reality often not encountered at the interfacelevel of present-day bureaucracies. In the following section, I discuss the implications of many tax collectors' feelings of abandonment by the state in their everyday work.

\section{How the denial of rights fuels bureaucratic pathologies}

At a more general level, the Egyptian tax administration's effectiveness in enforcing laws is hampered by 'bureaucratic pathologies' the kind of which we can observe elsewhere in the Egyptian state apparatus, and in fact throughout much of the developing world. Idleness and absenteeism, corruption, or the pushing out of committed employees all mean that vital tasks are not carried out by an honest, motivated, competent, and hardworking work force.

A key theme emerging from field interviews, internal tax administration documents, and press articles is that many tax collectors feel that the state has abandoned them and does not hold up its end of the bargain. ${ }^{17}$ They expect minimum levels of material and moral support from the state in exercising their jobs. The official discourse of the administrative leadership again acknowledges these rights. In a letter written by the ETA commissioner to the staff he repeatedly mentions the employees' 'material and moral rights' he vows to uphold and protect. ${ }^{18}$ But, mirroring the sentiment of many taxpayers who feel that they get nothing in exchange for their taxes, numerous tax 
collectors also believe that they 'don't get anything in exchange for their work' from the state, as even an employee of the elite LTC admitted. ${ }^{19}$

Working conditions, in particular, are considered insufficient to carry out one's duties appropriately and conflict with ideas of what the working environment of an Egyptian tax collector should be like. A sales tax department employee for instance explained: ${ }^{20}$

As a respectable state, I want from my employee that he works. So I need to provide some basic necessities. [...] So I prepare for him a respectable place, a humane place, [...] The state should provide the employee a new and clean building which is well equipped and less crowded, [in a] spacious place with parking space and services. And then he comes and can sit down with the taxpayer. I have a computer in every office, this computer is connected to a network from which I can get any data on every taxpayer. I can look at the social security and have a look: How many employees does he have? ${ }^{21}$

Needless to say, the reality does not look like this, though working conditions are not poor across the board.

But for tax collectors these material and moral rights also encompass an entitlement to a decent salary, decent public services, and more broadly a 'good life'. ${ }^{22}$ In particular the perceived inadequacy of the salary was often criticised, such as by this midlevel ETA official:

The tax collector feels unjustly treated in terms of his salary. It doesn't give me the strength to do my job. Things got worse and worse, also with corruption. ${ }^{23}$

In a context where workers feel deprived of the expected standard of moral and material support from the state, some may feel that 'going to steal' is the only logical consequence, whether they actually do it themselves or not. ${ }^{24}$

Indeed, petty corruption, as opposed to grand corruption at the level of the administrative and political leadership, was widely considered a very understandable consequence of the continuous 'economic strangling' 25 of civil servants, who are 'already in terms of their salaries some of the worst placed people in Egypt ${ }^{, 26}$ It is indeed crucial to see corruption not simply as an exogenous, irremediable factor in weak tax collection 
but to understand processes of legitimation from 'the actors' point of view' as well as in their historical context (Olivier de Sardan, 1999, p. 25). The Cairo sales tax collector mentioned above saw its spread explicitly in terms of a general déclassement of Egyptian civil servants since the 1970s:

After the Infitah [Open Door Policy], after el-Sadat, [...] there was a break with the civil servants. The living standards decreased, the income per month of specific sectors increased, and the government official['s income] didn't increase with them. [...]. The civil servant wants to feed his children and wants to educate them, he sees people around him, a plumber, a mechanic, a technician, and they have money. When they come and do something in the apartment they ask for a huge sum. It eats his entire budget. He begins to start looking at other ways out. Some people continue to live like that [...] but some work in the afternoon, some people take bribes, some do other things. [...] in 2002 in the sales tax authority the percentage of corrupt people didn't exceed 20 per cent, it got now to approximately 60 per cent. The reason is again the economic strangling. [...] There comes an honest young man, he stays honest for a while, suddenly he wants to feed his son, wants to bring him presents, wants to give him toys, he wants to live in an area that's a bit better than where he grew up, so he sees that his salary doesn't suffice. ${ }^{27}$

The promise of upwards social mobility that once came with a good position in the civil service, such as a job in the income or sales tax administration, is viewed as unrealistic if one does not moonlight or engage in corruption. Nazih Ayubi shared this view, arguing that if corruption, 'looseness', and a poor work ethic spread so visibly during the 1970s, it was largely because of the rampant 'commercialism' and the loss of status that civil servants suddenly experienced (Ayubi, 1980, p. 72).

This material deprivation is certainly grounded in objective and absolute trends of decreasing purchasing power. However, I argue that it is equally important to consider the status decline in relative terms as well, vis-à-vis the expectations people have both of their job and of their position in society.

Indeed, data on the absolute evolution of wages in the civil service and in the tax administration does not neatly square with the widespread social discontent observed throughout the country in the 2000 s and early 2010s. There were clear periods of real wage erosion, above all in the 1990s. Based on labour market surveys carried out between 1988 and 2012, Mona Said showed that between 1988 and 1998 median real wages of 
civil servants plummeted massively (-25\%) (Said, 2015). But they then recovered in the period from 1998 to 2012 (Said, 2015, p. 9). It is important to remember that this data is for all civil servants. Tax collectors are likely to have fared decently in the second half of the 2000 s, as the pay of general tax authority employees was increased in the wake of the merger with the sales tax authority and real estate tax collectors managed to win significant pay rises. ${ }^{28}$ However, in relative terms, the share of government employees below the low earnings level stood at 39 per cent in 1988, increased to 60 per cent in 1998, decreased to 35 per cent in 2006, and rose again to 43 per cent in 2012 (Said, 2015, p. 10). In other words, more civil servants were poor in 2012 than in 1988.

This is very much in line with the general perception of the situation by tax workers I encountered during fieldwork, which was one of being socially demoted. Tax collectors feel that the importance of their job, the status and what it entails, should warrant much greater appreciation. This sense of abandonment is strongly reinforced by the self-perception of tax collectors as a key group for society, both practically and morally in terms of the public good. Repeatedly, they argued that they generate the lion's share of the resources the state needs to function, as some of my informants explained at an event organised in the wake of the protests against the civil service reform:

We are an authority that brings you LE420 billion [roughly US $\$ 47 \mathrm{bn}$ at the time of fieldwork]. [...] You have to value the workers of the ETA and value the more than 70 per cent of the state's revenue that we bring you. ${ }^{29}$

An angry tax collector protesting the new civil service law in August 2015, which critics feared would result in worse compensation, shouted into the camera:

The government entity most hit by the civil service reform is the tax authority! I audit companies that sell for LE20m [US\$2m]! I am expected to take care of my appearance, support my family, $[\ldots]$ The government is telling people, go and steal! ${ }^{30}$

Specifically this latter quote very much illustrates how tax collectors view themselves as harder hit by social demotion than other civil servants. They view themselves as the face 
of the state and a symbol of the social contract, and recent modernisation efforts pushing for quality 'customer service' has only further increased pressure on tax workers.

Some employees explicitly frame their engagement explicitly in moral, patriotic terms. They say that they 'work to get money for Egypt, for the national budget.' ${ }^{31}$ An ETA employee from the central Cairo tax office of Abdin, who went public with accusations of corruption in the corporate tax office and was subsequently transferred to his current position, expressed his frustration the following way:

Since I was young I have been bringing in money for the state; they should build me a statue. Not because I like the fame, but because it's the right thing and this is the truth. ${ }^{32}$

The consequences of this perceived lack of recognition and breaking of what is effectively seen as a 'moral contract' between the state and the tax collectors are numerous (Bierschenk, 2014; Lentz, 2014). Most directly, they lead to the frustration and marginalisation of some of the most committed, motivated, and upright employees, who may at some point find their skills and talent to be more appreciated in the private sector or in administrations abroad. ${ }^{33}$ To give examples from my informants, one left to work in a tax administration in a Gulf country, others who have criticised the problems within the administration been marginalised or pushed to quit.

But perhaps more importantly, the perceived failure of the state to fulfil its duty vis-à-vis the employees results in many civil servants, or even prospective civil servants, adopting a more cynical attitude according to which one does not need to do any serious work. A number of scholars working on Egypt have described, in quite some detail, the problems of absenteeism, idleness, and low work morale (Abdel-Basset, 2009; Ayubi, 1980; Palmer et al., 1988). In the tax administration, the problem seems to be deeply rooted as well. A street-level auditor in the sales tax authority explained, for instance:

Let me tell you the problems of work. Our tax collectors... [...] I mean, those of the audit, surveying, and collection departments who are the economic backbone of the tax administration. Their number at the level of the entire [sales] tax administration does not 
exceed 4,000 employees. Out of 22,000 employees. I have another 8,000 who support them and do administrative work with operations, legal affairs, and so forth. Everybody that works, in the entire entity amounts to 12,000 , and 10,000 is disguised unemployment. ${ }^{34}$

Other experts, such as a consultant of the USAID technical assistance project that accompanied tax reform in Egypt for several years also estimated that somewhere between one-third and two-thirds of employees may be superfluous. ${ }^{35}$ Indeed, during several of my own visits to tax offices I came across large open-plan offices where employees were sitting at empty desks not doing any visible work, or chatting with colleagues.

Interestingly, higher-ups in the administration seem to largely agree with the narrative that the state is not holding up its end of the social contract. This can result in managers finding it inappropriate to be too demanding of their subordinates. Palmer et al.'s work, for example, showed that such considerations do exist and matter for mid- or upper-level management (Palmer et al., 1988). They write: 'One senior official expressed the sentiment as, 'we pay them so little, how can I ask them to do more?' (Palmer et al., 1988, p. 85). In other words, it is sometimes also the realisation of top-level officials themselves that the state does not fulfil commonly held views of acceptability that will shape their willingness to enforce bureaucratic discipline, a point which I shall further develop in the following section.

\section{How a moral economy of bonuses hinders performance-based management}

Absenteeism, idleness, and corruption are of course not only the product of disappointed expectations, but also of an institutional environment that does not push many tax collectors to change their ways. Legally, there are mechanisms through which employees could be disciplined - for example, by withholding parts of their bonuses or salary - but these are not being used, or only in their mildest form. ${ }^{36}$ In other words, a 'practical norm' 
is at work, which Jean-Pierre Olivier de Sardan called 'sanctioning is inappropriate' (Olivier de Sardan, 2008, 2014, p. 408). ${ }^{37}$

In the Egyptian tax administration, it is not as if there was a lack of means to monitor what employees are doing, as principal-agent theory would have us believe (Mukherjee, 2001, pp. 5-6). Co-workers and mid-level office managers tend to know quite well who comes to work and at what time, and who does what job well or poorly. ${ }^{38}$ The unwillingness of managers to 'rock the boat' and create discontent among staff or their fear of damaging their career is a more convincing explanation. However, it is also important to consider the fact that top-level officials may buy into a normative consensus about the legitimate rights of employees, of what they deserve to get from the state. A good example of this is what could be called the 'moral economy of bonuses'.

In the Egyptian bureaucracy, including the tax administration, virtually everybody gets the full amount of bonuses, incentives, and rewards they can earn. Therefore, not granting an employee the full package will almost always be perceived by managers and subordinates alike as a denial of their rights. The same logic applies to performance evaluations of employees. Virtually all employees get flawless reviews, and therefore people will perceive deviations from this as a punishment.

This is largely a consequence of how the civil service has evolved over time. The public administration built throughout the $20^{\text {th }}$ century was one in which progression by seniority alone was the norm and modern performance-based management was less influential. In a context of massive erosion of social status of civil servants, it became an implicit consensus that they have a right to every piastre they can get, whether it is part of a technically variable part of the salary or not. So neither the performance evaluation nor the reward are actually perceived by employees as something linked to any actual work effort, but instead as a right, an entitlement. 
All the more so that over time the base salary of Egyptian civil servants has become an ever-decreasing part of their remuneration. While in developed countries, the variable part of the income usually does not exceed 10 per cent of the grand total, in Egypt the 'variable' part of the total salary could indeed reach up to 85 per cent. ${ }^{39}$ As civil service salaries are, already quite low in comparison to many professions in the formal private sector and increases rarely kept pace with the cost of living, it would be extremely detrimental to employees to take the variability of salaries seriously.

This moral economy of bonuses then feeds back into the aforementioned dynamics of avoidance of social discontent that are also at play. Managers know that the system of bonuses is considered a right by their subordinates, so challenging this status quo means to run the risk of 'rocking the boat'. Albeit not from a tax official, a quote from a manager in the public administration interviewed by Nada Abdel-Basset is revealing:

I recall one of my subordinates whom I once gave 95 per cent on her annual performance appraisal - which is still 'Excellent'. This subordinate reported to my superior that I was discriminating against her because she used to take between $98-100 \%$ every year. Should a supervisor be fair and objective about appraising the performance of subordinates, he will be reported as discriminating against his subordinates and being unfair. (AbdelBasset, 2009, p. 209)

The fact that more recently, tax collectors' strikes, sit-ins, and protests have very often focused on the regular increase of bonuses and their timely pay out further underscores the strong feelings of entitlement to full bonus pay. ${ }^{40}$ And therefore, since many employees will get everything anyway they will not make much of an effort to carry out an often quite unpleasant job. ${ }^{41}$

Thus, an important part of Egypt's - and without a doubt of many developing countries' - problem with the weakness of its management practices seems not so much related to difficulties in obtaining information but rather to the practical norm against sanctioning rooted in the fact that variable pay is considered to be part and parcel of the 
PSB. This highlights the fact that institutions, the incentives they create, as well as how people respond to them, depends to a significant extent on historically rooted norms, ideas, and expectations.

\section{Conclusion}

This article showed how broken expectations of a certain employer-employee relationship with the state shape the way tax collectors do their job. How conceptions of the social contract, norms, and beliefs shape taxpayers' willingness to pay taxes has been well studied. How this affects the willingness of tax collectors to collect them had thus far been a blind spot in the literature.

Crucially, the role of broken public service expectations does not stop at lowering job motivation, creating tensions between street-level bureaucrats and top-level officials, or legitimising corruption. They affect the entire functioning of the public administration from the building of administrative capacity to internal management processes. Concepts such as state capacity have been criticised for their perceived technical and material nature that ignores the political agency of actors (Hameiri, 2007; Matthews, 2012). Going even further than that, I would argue that they have paid insufficient attention to their most concrete and organic manifestation, the civil servant, understood as an individual strategic actor in its real-life, historical, cultural and sociological contexts.

This of course then questions the wisdom of many donor-funded technical assistance programmes for which tax administrations and their staff are essentially the same in all contexts, as if there existed a 'homo publicanus', ${ }^{42}$ and in which improving the situation and morale of ordinary tax collectors has historically been a secondary concern. A final USAID report of the programme that accompanied the tax reforms of the 2000s in Egypt for instance covers its achievements in the area of tax administration 
over several pages, but there is no mention of structural problems around job satisfaction or performance-based management. ${ }^{43}$ Instead, the focus lies on organisational restructuring, technological modernisation and skills development. More recent donor guidelines engage more with creating a better-managed, inclusive and motivating tax administrations but ultimately still fail to reflect on broader trends affecting the social position of the tax collector. ${ }^{44}$

What, then, could states do to address these issues and ensure more effective enforcement of tax laws? There are numerous possibilities. If the required effort to get interface-level tax workers to strictly enforce tax collection is too costly, it may not be worth insisting on it, and a stricter enforcement among wealthier, more formal, sectors of society could be preferable (Keen, 2013; Meagher, 2016). Tax administrations could also diversify their recruitment by relaxing higher education requirements and investing in apprenticeships or on-the-job training for some of their jobs and tasks. But the negative image of interface-level tasks would still need to be addressed, ideally by more generous compensation, improved co-operation with the police, and better prospects for promotion. More generally, higher investments in working conditions and in pay that allows for a decent life are necessary. This may be costly, but in comparison to wage increases in other public administrations the investment may actually be offset by higher government revenues.

Last but not least, the article emphasises the promise of further probing the working realities of ordinary tax collectors. Our insights into the world of everyday tax collection often remain relayed by top-level managers, experts, and consultants, or politicians. Both ethnographic methods and surveys could be harnessed to address this.

\footnotetext{
${ }^{1}$ If we run a simple multivariate regression using GDP per capita (PPP), the share of external rent, literacy rates, the level of democracy, perceived corruption levels, and the share of agriculture in the GDP, Egypt's tax-to-GDP ratio is 0.6 standard deviations lower than the model would predict. Own calculations using the International Centre for Tax
} 
and Development (ICTD) Government Revenue Dataset as well as the Quality of Government Dataset (Prichard et al., 2014; Teorell et al., 2019).

${ }^{2}$ The tax effort is the ratio of the actual tax collection to predicted collection (typically calculated using various socioeconomic indicators).

${ }^{3}$ Data for developed countries: (OECD, 2011, pp. 67-68) and for Egypt own interviews (2013-2014).

4 Thomas Bierschenk calls these historical processes of bureaucratic continuity and change 'sedimentation' (Bierschenk, 2014, p. 213).

${ }^{5}$ Formally, Nasser did not assume leadership until he became president of the republic in 1954. However, Nasser had been the leader of the Free Officers who perpetrated the bloodless coup which overthrew the monarchy on July 23, 1952.

${ }^{6}$ Interview with tax collector 3 and group 1 of tax collectors, February 4, 2014. Between 2013 and 2015, after a few years on the job, an average tax worker can expect to make about 2,000 to 3,000 Egyptian pounds (LE) a month (about US $\$ 300-U S \$ 400$ at the time). After about 15 years of service, a salary of about LE4,000 a month was possible. Egypt's national statistics institute CAPMAS does not publish median salary figures for civil servants, only averages distorted by the inclusion of the often highly paid managerial class. One can estimate that during the same time period a significant part of rank-and-file civil servants earned salaries between the minimum wage (LE1,200 per month) and about LE2,000 a month, or roughly US\$150 and US\$275 dollars a month respectively.

${ }^{7}$ There are two tax administrations because until 1937, Egypt was bound by the Capitulations which made income taxation of most foreigners contingent on the approval of European powers. Since the latter was not granted, governments also refrained from imposing such taxes on Egyptians. Only after their abolition was Egypt able to create income taxes and opted for a dedicated administration.

${ }^{8}$ Interview with tax collector 12, August 19, 2015.

${ }^{9}$ The current Egyptian president Abdel Fattah el-Sisi grew up in this neighbourhood.

${ }^{10}$ Interview with tax collector 5, July 8, 2014.

${ }^{11}$ Interview with tax collector 2, May 29, 2014.

${ }^{12}$ Interview with tax collectors 7 and 8, May 2014; Interview with tax collector 9, January 2014.

${ }^{13}$ Interview with tax collector 3, February 22, 2014; Interview with tax collector 2, July 10, 2014.

${ }^{14}$ Interview with tax collector 5, July 8, 2014; Interview with tax collector 3 and group 1 of tax collectors, February 4, 2014.

${ }^{15}$ Interview with tax collector 2, July 10, 2014, Interview with tax collector 3, February 22, 2014.

16 'Protests of Haram and Faisal sales tax workers after decision to move to Monib', November 25, 2015,

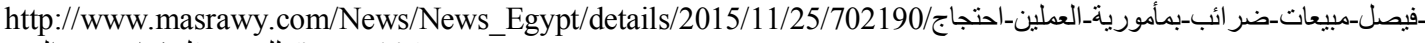
(in Arabic).

${ }^{17}$ This idea is again not exclusive to Egyptian tax collection but has been observed in other regional contexts and realms of state-society relations (Bierschenk, 2014; Lentz, 2014).

${ }^{18}$ Internal letter from the tax commissioner on the merger of the general and sales tax departments into the Egyptian Tax Authority, January 2007, http://www.ltc.gov.eg/pdf/message.pdf. Own translation.

${ }^{19}$ Interview with tax collector 14, September 27, 2015.

${ }^{20}$ Over the course of my field work I visited about five or six buildings of various tax administrations, most of them in Cairo, but also one in Ismailia.

${ }^{21}$ Interview with tax collector 2, July 10, 2014.

${ }^{22}$ Interview with tax collector 2, July 10, 2014

${ }^{23}$ Interview with tax collector 13, August 26, 2015

${ }^{24}$ Interview with tax collector 15, August 29, 2015

${ }^{25}$ Interview with tax collector 2, July 10, 2014

${ }^{26}$ Interview with tax collector 10, August 13, 2015.

${ }^{27}$ Interview with tax collector 2, July 10, 2014.

${ }^{28}$ Interview with former minister of Finance, March 1, 2017.

${ }^{29}$ Tax collectors 17 and 10, recorded on: 'Head of the sales tax union: the ministries of finance and planning sow division between the people and the government' (translated title), Masr El Arabiya, August 15, 2015 (https://www.youtube.com/watch?v=2NekEBZbJy4)

30 'Tax authority employees protest civil service law', Al Ahram Online, August 10, 2015 (https://www.youtube.com/watch?v=uQXmJvddj6g)

31 'Tax collector from Abdin exposes irregularities in the ETA', Sawt el Umma, February 2, 2015 (https://www.youtube.com/watch?v=TD_ZqTgMB2A\&spfreload=10)

32 'With documents: '90 minutes' opens the file of the waste of millions because of tax evasion' (translated title), 90 Minutes, El Mehwar, June 11, 2015 (https://www.youtube.com/watch?v=pQxgPr8EUlc)

33 'Tax collectors: We suffer from low salaries and many left for the private sector', El Watan, October 18, 2018 (https://www.elwatannews.com/news/details/3726337)

${ }^{34}$ Interview with tax collector 2, July 10, 2014.

${ }^{35}$ Interview with consultant 1, May 2010.

${ }^{36}$ Interview with tax collector 2, July 10, 2014, Interview with tax collector 3, February 22, 2014.

${ }^{37}$ Practical norms are ones that are neither official (laws, rules, regulations) nor social (societal norms, conventions) norms, but describe the divergence between official norms and the reality of concrete practice in everyday life, that is between what should happen if the official rules were followed and what happens in reality.

${ }^{38}$ Interview with tax collectors 1 and 2, July 10, 2014; Interview with tax collector 3, February 22, 2014; Interview with tax collector 5, July 8, 2014. 
${ }^{39}$ The civil service reform passed in October 2016 intended to reverse this ratio.

${ }^{40}$ Interviews with employees of the ETA in Yqeen news report on a tax workers' conference entitled 'The Tax Authority between Theory and Practice', published on March 12, 2015 (https:/www.youtube.com/watch? $\mathrm{v}=0$ ZAEtF9chg). Own translation.

${ }^{41}$ Interview with tax collector 3, February 22, 2014.

42 The ancient Roman publicani or publicans were officials to whom, amongst other duties, the collection of many taxes were contracted out. I use the term here to simply mean "tax collector".

${ }^{43}$ Final Report, Technical Assistance for Policy Reform II, January 20, 2011

${ }^{44}$ Detailed Guidelines for Improved Tax Administration in Latin America and the Caribbean, August 2013. 


\section{References}

Abdel-Basset, N. A. (2009) Developing Commitment Towards Change in

Bureaucracies: The Case-Study of the Egyptian Civil Service Sector, PhD. University of Stirling, Stirling.

Adly, A. (31/01/2015) Triumph of the Bureaucracy: A Decade of Aborted Social and Political Change in Egypt. Jadaliyya - جدلية. Accessed: 30th January 2019

$<$ http://www.jadaliyya.com/Details/31735. $>$.

Ahmed, S. (1984) Public finance in Egypt: its structure and trends. (Vol. 1). World Bank.

Alesina, A., and Fuchs-Schündeln, N. (2007) Goodbye Lenin (or Not?): The Effect of Communism on People's Preferences. American Economic Review 97(4): 1507-1528. Assaad, R. (1997) The effects of public sector hiring and compensation policies on the Egyptian labor market. The World Bank Economic Review 11(1): 85-118.

Ayubi, N. (1980) Bureaucracy \& Politics in Contemporary Egypt. Reading, UK: Ithaca Press.

Beinin, J. (2009) Workers' Protest in Egypt: Neo-liberalism and Class Struggle in 21st Century. Social Movement Studies 8(4): 449-454.

Berman, S. (2001) Ideas, Norms, and Culture in Political Analysis. (Inglehart, R., Katzenstein, P., Laitin, D., and McNamara, K., Eds.)Comparative Politics 33(2): 231250.

Best, M. (1976) Political power and tax revenues in Central America. Journal of Development Economics 3(1, March): 49-82.

Bierschenk, T. (2014) Sedimentation, Fragmentation and Normative Double-Binds in (West) African Public Services. In Bierschenk, T. and Olivier de Sardan, J.-P. (Eds.), States at Work - Dynamics of African Bureaucracies. Brill. 
Bierschenk, T., and Olivier de Sardan, J.-P. (2014) Ethnographies of Public Services in Africa: An Emerging Research Paradigm. In Bierschenk, T. and Olivier de Sardan, J.-P. (Eds.), States at Work: Dynamics of African Bureaucracies. Brill.

Bird, R. M. (1989) The administrative dimension of tax reform in developing countries. In Gillis, M. (Ed.), Tax Reform in Developing Countries. Duke University Press.

Bishara, D. (2015) The politics of ignoring: Protest dynamics in late Mubarak Egypt. Perspectives on Politics 13(4): 958-975.

Cirolia, L. R., and Mizes, J. C. (2019) Property Tax in African Secondary Cities: Insights from the Cases of Kisumu (Kenya) and M'Bour (Senegal). The International Centre for Tax and Development (ICTD) (Working Paper 90).

D'Arcy, M. (2011) Why do citizens assent to pay tax? Legitimacy, taxation and the African state, Working Paper No. 126. Afrobarometer.

Fairfield, T. (2015) Private Wealth and Public Revenue. Cambridge University Press. Farag, I. (2001) Un emploi pour un diplôme - L'usure d'un accord tacite (1930-1990). Égypte/Monde arabe 2001/4-5: 173-190.

Fukuyama, F. (2004) The Imperative of State-Building. Journal of Democracy 15(2): $17-31$.

Goodfellow, T., and Owen, O. (2018) Taxation, Property Rights and the Social Contract in Lagos, Working Paper No. 73. Institute of Development Studies. Hameiri, S. (2007) Failed states or a failed paradigm? State capacity and the limits of institutionalism. Journal of International Relations and Development 10(2): 122-149. Helmke, G., and Levitsky, S. (2004) Informal Institutions and Comparative Politics: A Research Agenda. Perspectives on Politics 2(4): 725-740.

Holland, A. C. (2016) Forbearance. American Political Science Review 110(2): 232246. 
Hood, C. (2000) Paradoxes of public-sector managerialism, old public management and public service bargains. International Public Management Journal 3(1): 1-22.

Hood, C., and Lodge, M. (2006) The Politics of Public Service Bargains: Reward, Competency, Loyalty - and Blame. OUP Oxford.

Joshi, A., and Ayee, J. (2008) Associational taxation: A pathway into the informal sector? In Brautigam, D., Fjeldstad, O.-H., and Moore, M. (Eds.), Taxation and StateBuilding in Developing Countries - Capacity and Consent. Cambridge University Press. Joshi, A., Prichard, W., and Heady, C. (2012) Taxing the Informal Economy: Challenges, Possibilities and Remaining Questions, Working Paper No. 4. Institute of Development Studies.

Kapiszewski, D., MacLean, L. M., and Read, B. L. (2015) Field Research in Political Science: Practices and Principles. Cambridge University Press.

Keen, M. (2013) Taxation and Development - Again. In Fuest, C. and Zodrow, G. R. (Eds.), Critical Issues in Taxation and Development. MIT Press.

Lachapelle, J. (2012) Lessons from Egypt's Tax Collectors. Middle East Report 42(264): 38-41.

Le, T. M., Moreno-Dodson, B., and Bayraktar, N. (2012) Tax capacity and tax effort: Extended cross-country analysis from 1994 to 2009, Working Paper. World Bank. Lentz, C. (2014) "I take an oath to the state, not the government": career trajectories and professional ethics of Ghanaian public servants. In Bierschenk, T. and Olivier de Sardan, J.-P. (Eds.), States at Work: Dynamics of African Bureaucracies. Brill. Levi, M. (1988) Of Rule and Revenue. University of California Press. Lipsky, M. (1980) Street-Level Bureaucracy: The Dilemmas of the Individual in Public Service. Russell Sage Foundation. 
Mann, M. (1984) The autonomous power of the state: its origins, mechanisms and results. European Journal of Sociology / Archives Européennes de Sociologie 25(02): $185-213$.

Matthews, F. (2012) Governance and State Capacity. In Levi-Faur, D. (Ed.), The Oxford Handbook of Governance. OUP Oxford.

Maynard-Moody, S., and Musheno, M. (2012) Social Equities and Inequities in Practice: Street-Level Workers as Agents and Pragmatists. Public Administration Review 72(s1): S16-S23.

Meagher, K. (2016) Taxing Times: Taxation, Divided Societies and the Informal Economy in Northern Nigeria. Journal of Development Studies 54(1): 1-17.

Moore, M. (2014) Revenue Reform and Statebuilding in Anglophone Africa. World Development 60: 99-112.

Mukherjee, R. (2001) Total Rewards for Civil Servants, Working Paper. PREM Network.

O’Brien, K. J., and Li, L. (1999) Selective Policy Implementation in Rural China. Comparative Politics 31(2): 167-186.

OECD (2011) Tax Administration in OECD and Selected Non- OECD Countries: Comparative Information Series (2010). OECD.

Olivier de Sardan, J.-P. (2008) Researching the practical norms of real governance in Africa, Working Paper No. 5. Overseas Development Institute.

Olivier de Sardan, J.-P. (2014) The Delivery State in Africa. Interface Bureaucrats, Professional Cultures and the Bureaucratic Mode of Governance. In Bierschenk, T. and Olivier de Sardan, J.-P. (Eds.), States at Work - Dynamics of African Bureaucracies. Brill. 
Palmer, M., Leila, A., and El Sayed, Y. (1988) The Egyptian Bureaucracy. Syracuse University Press.

Pessino, C., and Fenochietto, R. (2010) Determining countries' tax effort. Revista de Economía Pública 195(4/2010): 65-87.

Piracha, M., and Moore, M. (2016) Revenue-Maximising or Revenue-Sacrificing Government? Property Tax in Pakistan. Journal of Development Studies 52(12): 17761790.

Posner, E. A. (2000) Law and Social Norms: The Case of Tax Compliance. Virginia Law Review 86(8): 1781-1819.

Prichard, W. (2009) The politics of taxation and implications for accountability in Ghana 1981-2008, Working Paper No. 330. Institute of Development Studies. Prichard, W., Cobham, A., and Goodall, A. (2014) The ICTD Government Revenue Dataset, Working Paper No. 19. Institute of Development Studies.

Prichard, W., and van den Boogaard, V. (2017) Norms, Power, and the Socially Embedded Realities of Market Taxation in Northern Ghana. African Studies Review 60(1): 171-194.

Radian, A. (1980) Resource Mobilization in Poor Countries: Implementing Tax Policies. Transaction Publishers.

Said, M. (2015) Wages and inequality in the Egyptian labor market in an era of financial crisis and revolution. In Assaad, R. and Krafft, C. (Eds.), The Egyptian Labor Market in an Era of Revolution. Oxford University Press.

Sen, A. K. (1977) Rational Fools: A Critique of the Behavioral Foundations of Economic Theory. Philosophy \& Public Affairs 6(4): 317-344.

Soliman, S. (2011) The Autumn of Dictatorship: Fiscal Crisis and Political Change in Egypt under Mubarak. Stanford University Press. 
Tanzi, V., and Zee, H. H. (2000) Tax Policy for Emerging Markets: Developing Countries. National Tax Journal 53(2): 299-322.

Tendler, J. (2002) Small Firms, the Informal Sector, and the Devil's Deal. IDS Bulletin 33(3): 1-15.

Teorell, J., Dahlberg, S., Holmberg, S., Rothstein, B., Alvarado Pachon, N., and Svensson, R. (2019) The Quality of Government Standard Dataset, version Jan 19. University of Gothenburg: The Quality of Government Institute.

Twijnstra, R., Hilhorst, D., and Titeca, K. (2014) Trade networks and the practical norms of taxation at a border crossing between South Sudan and Northern Uganda. Journal of Eastern African Studies 8(3): 382-399.

von Soest, C. (2007) How Does Neopatrimonialism Affect the African State's Revenues? The Case of Tax Collection in Zambia. Journal of Modern African Studies 45(4): 621-645.

von Soest, C., Bechle, K., and Korte, N. (2011) How Neopatrimonialism Affects Tax Administration: a comparative study of three world regions. Third World Quarterly 32(7): 1307-1329.

Waterbury, J. (1997) From Social Contracts to Extraction Contracts. In Entelis, J. P. (Ed.), Islam, Democracy, and the State in North Africa. Indiana University Press. Wenzel, M. (2005) Motivation or rationalisation? Causal relations between ethics, norms and tax compliance. Journal of Economic Psychology 26(4): 491-508. Winter, S. (2000) Information asymmetry and political control of street-level bureaucrats: Danish agro-environmental regulation. Institut for Statskundskab, Aarhus Univesrsitet. 


\section{Acknowledgments}

I would like to extend my warm thanks to the Centre d'Études et de Documentation, Économiques, Juridiques et Sociales in Cairo, Egypt, and in particular to their head and former head respectively, Karine Bennafla and Bernard Rougier, for hosting me during my time in the field. I am also very appreciative of funding support by the Cusanuswerk foundation and the LSE Middle East Centre. I am further extremely grateful to numerous people who have commented on earlier outputs of this research project and/or this article, in particular Steffen Hertog, Catherine Boone, Steven Heydemann, John Chalcraft, Portia Roelofs, the participants of a "Normative Politics in Africa" workshop series at LSE and Oxford University, Geoffrey Swenson, Jonathan Weigel, J. Robert Basedow, Max Gallien, Kate Meagher, Ryan Sailor and my panel at the 2018 Annual Meeting of the American Political Science Association. I also wish to thank the Department of International Development at LSE and in particular Jean-Paul Faguet and Ken Shadlen for their support. Finally, I thank three anonymous reviewers for their insightful comments.

\section{Declaration of Interest Statement}

I have no competing or conflicting interests to declare. 